\title{
Das Böse, der Teufel und Dämonen - Evil, the Devil, and Demons
}

\author{
Hrsg. v./Ed. by Jan Dochhorn, Susanne Rudnig-Zelt u./and Benjamin Wold
}

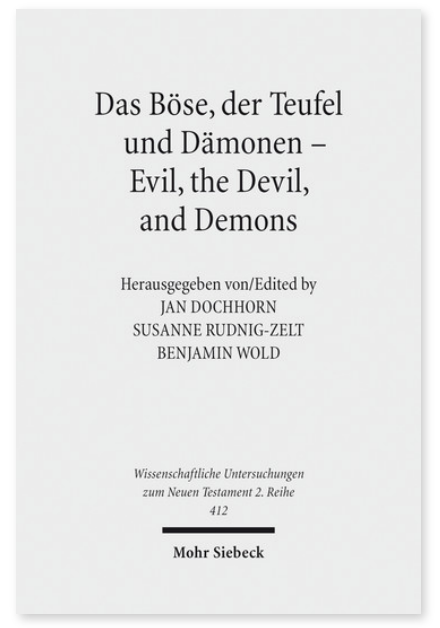

2016. XIV, 297 Seiten. WUNT II 412

ISBN 978-3-16-153633-5

DOI 10.1628/978-3-16-153633-5

eBook PDF $99,00 €$

ISBN 978-3-16-152672-5

fadengeheftete Broschur 99,00€
Im Zentrum des vorliegenden Sammelbandes steht die Frage nach dem Bösen in Religionen, die als monotheistisch verstanden werden oder für die zumindest die Herrschaft des Hauptgottes über alle anderen Götter und Mächte ein entscheidendes Anliegen ist. Der Schwerpunkt liegt auf dem sich formierenden Judentum und Christentum sowie dem Alten Testament als dem Buch, das beide Religionen maßgeblich beeinflusst hat. Besonderes Interesse gilt den Texten aus Qumran, und darüber hinaus erfolgt ein Blick auf mittelalterliche Heiligenlegenden. Die Beiträge des Bandes zeigen, dass es in den antiken jüdischen und christlichen Texte eine große Vielfalt von Verkörperungen des Bösen gibt, sei es extern als Dämon oder Teufel, sei es intern als die menschliche Fähigkeit, Böses zu tun. Prinzipiell wurden also schon in der Antike beide Wege beschritten. Das Böse wurde sowohl internalisiert als auch durch außermenschliche Figuren verkörpert oder mit innen in Verbindung gebracht. Außerdem stellt sich heraus, dass in der jüdisch-christlichen Literatur Dualismus nicht grundsätzlich abgelehnt wird, aber nur Formen von Dualismus vorkommen, in denen das Böse Gott und dem Guten letztlich untergeordnet ist. Die Autoren erläutern, wie man in der Antike und im Mittelalter versuchte, mit dem Bösen zu Rande zu kommen und stellen vielfältige Erzählungen vom Bösen und seiner Rolle in der Schöpfung vor. Ob sich in einer dieser Erzählungen schon »Accommodating 'Evil'« vollzogen hat, liegt Ermessen des Lesers.

\section{Inhaltsübersicht}

Susanne Rudnig-Zelt: Einleitung Altes Testament/Old Testament Susanne Rudnig-Zelt: Der Teufel und der alttestamentliche Monotheismus - Markus Saur: Der Blick in den Abgrund. Bilder des Bösen in der alttestamentlichen Weisheitsliteratur Qumran Matthew Goff: Enochic Literature and the Persistence of Evil: Giants and Demons, Satan and Azazel - Miryam T. Brand: Belial, Free Will, and Identity-Building in the Community Rule - Matthew Goff: A Seductive Demoness at Qumran? Lilith, Female Demons and 4Q184 Neues Testament/New Testament Michae/ Morris: Apotropaic Inversion in the Temptation and at Qumran - Benjamin Wold: Apotropaic Prayer and the Matthean Lord's Prayer - Erkki Koskenniemi: »For we are unaware of his schemes«: Satan and Cosmological Dualism in the Gentile Mission - Jan Dochhorn: Die Bestrafung des Unzuchtsünders in 1. Kor 5,5: Satanologische, anthro-pologische und theologische Implikationen - Oda Wischmeyer: Zwischen Gut und Böse. Teufel, Dämonen, das Böse und der Kosmos im Jakobusbrief - Jan Dochhorn: Kain, der Sohn des Teufels. Eine traditionsgeschichtliche Untersuchung zu 1. Joh 3,12 Spätantike und Mittelalter/Late Antiquity and Middle Ages Hector M. Patmore: Demons in Targum Jonathan. A Study of 2 Sam. 22.5; Isa. 13.21; 34.14; Hab. 3.5. - Jörn Bockmann: Judas und St. Brandan: Der Sünder, der Heilige und die Sabbatruhe von den Höllenqualen Übergreifende Perspektiven/General Perspectives Ryan E. Stokes: What is a Demon, What is an Evil Spirit, and What is a Satan?

Jan Dochhorn Geboren 1968; 2007-14 Lektor/Associate Professor für Neues Testament in Aarhus; seit 2014 Senior Lecturer/Associate Professor für Neues Testament in Durham (Vereinigtes Königreich).

Benjamin G. Wold Born 1974; BS Multnomah; MA Jerusalem University College; Ph.D. Durham University; Alexander von Humboldt-fellow, Tübingen University (Institut für antikes Judentum und hellenistische Religionswissenschaft).

Susanne Rudnig-Zelt Geboren 1971; Studium der Evangelischen Theologie sowie altorientalische, judaistische, kunsthistorische und philosophische Studien; 2005 Promotion; seit 2010 Wissenschaftliche Angestellte/Hebräischlektorin an der Theologischen Fakultät der Christian-Albrechts-Universität Kiel.

\section{Jetzt bestellen:}

https://mohrsiebeck.com/buch/das-boese-der-teufel-und-daemonen-evil-the-devil-and-demons-9783161536335?no cache=1 order@mohrsiebeck.com

Telefon: +49 (0)7071-923-17

Telefax: $+49(0) 7071-51104$ 